\title{
Rafae Biskup, Magdalena Pyter, Maciej Rudnicki, Jacek Trzewik (RED.), Dziatalność gospodarcza na ObSZaRach CHRONiONYCH, Wydawnictwo KUL, Lublin 2014, ss. 375
}

W trakcie swej pracy zawodowej współpracowałem z organizacjami społecznymi, których celem statutowym było działanie na rzecz ochrony dziedzictwa przyrodniczego. Dlatego też recenzowana pozycja wzbudziła moje zainteresowanie. Została wydana w 2014 r. przez Wydawnictwo Katolickiego Uniwersytetu Jana Pawła II, zredagowana przez Rafała Biskupa, Magdalenę Pyter, Macieja Rudnickiego i Jacka Trzewika. Stanowi pokłosie III konferencji Sieci Zrównoważonego Rozwoju „Działalność gospodarcza na obszarach chronionych", zorganizowanej na Wydziale Prawa, Prawa Kanonicznego i Administracji Katolickiego Uniwersytetu Lubelskiego Jana Pawła II w dniach 18-19 listopada 2013 r.

Książka zawiera dwadzieścia jeden rozdziałów, zamkniętych bibliografia, poprzedzonych wykazem skrótów i przedmową. Redaktorzy trafnie w niej napisali, iż „niekiedy wymogi wynikające z zasady zrównoważonego rozwoju kreują tak ważny interes publiczny, że dla jego ochrony konieczna jest nie reglamentacja, ale wyłączenie tej swobody" (s. 16). W nauce, co zostało podniesione na kartach książki, należy mówić nie tylko o ograniczeniach „inwestowania, prowadzenia działalności gospodarczej i tworzenia miejsc pracy na obszarach chronionych", co możliwościach „wykorzystania ich potencjału w działalności gospodarczej” (s. 16). Jest to słuszny trend badawczy, który skłania do spojrzenia na normy prawa ochrony środowiska w szerszym aspekcie, nie tylko pod kątem sankcji, ale szans i pozytywnych bodźców skierowanych do adresatów tychże norm.

Obawy przed rozszerzeniem obszarów chronionym mogą być w pewnej mierze niezasadne. Założyć można, iż obszary te są powiększane w rejonach peryferyjnych. Przy niskim poziomie rozwoju gospodarczego państwa, wysokim stopniu regulacji, skupianiu aktywności społecznej (w tym gospodarczej) w stolicy, uwarunkowaniach faktycznych kreowanych przez lokalne elity, ograniczenia nakładane na przedsiębiorców, w tym potencjalnych, mogą okazać się pozorne, gdyż i tak nikt na danym obszarze działalności gospodarczej by nie rozpoczął. Otwieranie zakła- 
dów przemysłowych może zaś nie przynosić dostrzegalnych korzyści, a generować straty tak ludziom, jak i środowisku naturalnemu. Niż demograficzny również przemawia na rzecz rozprzestrzeniania obszarów chronionych, tym bardziej, jeśli objęcie nimi pustek osadniczych byłoby korzystne dla ewentualnych inwestorów z branży turystycznej czy rolnictwa ekologicznego. Warto się zastanowić, czy zrównoważony rozwój nie jest aby „produktem” bogatego społeczeństwa Zachodu i co ta doktryna ma do zaoferowania kontynentom afrykańskiemu i azjatyckiemu. Już dziś obserwujemy efekt zderzenia się dogmatu postępu cywilizacyjnego z realiami imigracji, gdy sprzeczności między deklaracjami a polityką potęgowane są na tle religijnym. Tak istotne było więc zwrócenie uwagi przez autorów na aspekty prawnomiędzynarodowe. Dzięki autorom czytelnik obcuje ponadto ze swoistym językiem prawnym.

Redaktorzy podzielili recenzowaną monografię na trzy działy: 1) „Działalność gospodarcza na obszarach chronionych w koncepcji zrównoważonego rozwoju”, 2) "Zastosowanie norm publicznego prawa gospodarczego w ochronie środowiska”, 3) „Działalność gospodarcza a ochrona walorów krajobrazowych obszarów chronionych". Podział ten nie jest dla mnie zrozumiały, gdyż moim zdaniem tytuły działów nie mają pełnego odniesienia $\mathrm{w}$ treści zamieszczonych $\mathrm{w}$ nich rozdziałów. Tytuły artykułów również nie zawsze odpowiadają ściśle zawartości. Poza jednym wyjątkiem z działu pierwszego redaktorzy przyjęli wewnątrz działów układ alfabetyczny. Rozdziały prezentujące rozważania natury ogólnej zostały jednakże wplecione między teksty o szczegółowej tematyce. Wydaje mi się, że można było zrezygnować z wyodrębniania działów, a artykuły ułożyć bądź alfabetycznie, bądź tematycznie.

Rezygnując z przytaczania spisu treści, pragnąłbym krótko omówić wybrane rozdziały, grupując je alfabetycznie w następujące części: rozpraw o tematyce ogólnej, analiz orzecznictwa, szczegółowych opracowań z zakresu dogmatyki prawa i studiów przypadków.

Teoretycznej strony prawa dotknął Marcin Borowiak w rozdziale: Znaczenie dyrektywy jezzyka specjalistycznego w odkodowywaniu normy prawnej (na przykładzie ograniczeń obowiazujących na obszarach specjalnych o charakterze ekologicznym). Przeprowadził konstruktywną krytykę orzecznictwa, wzbogacacając teorię prawa o wątki szczegółowe. Jego multidyscyplinarne podejście i odwaga $\mathrm{w}$ formułowaniu sądów zasługują na uznanie. Stwierdzenie: „Niestety sądy administracyjne, w których orzekający sędziowie nie posiadają wiedzy specjalistycznej (...), nie są należycie przygotowane do kontroli wykładni przepisów prawa materialnego w oparciu o dyrektywę języka specjalistycznego, pomimo że stanowi to przedmiot 
ich kompetencji" (s. 169) jest wyraźną wskazówką także dla pełnomocników procesowych. Zdaniem M. Borowiaka nierzadko sąd zamiast odkodować normę prawna, opierając się na języku specjalistycznym, „tworzy (co czego nie jest uprawniony, gdyż nie może zastępować prawodawcy) normę zamienną w oparciu o nieuprawnioną wykładnię rozszerzającą lub ścieśniającą" (s. 168). Ubolewać więc można, iż część polskich sędziów nie zna terminologii, jaką stosuje ustawodawca.

Rzadziej spotykany w literaturze wątek krajobrazu jako dobra osobistego został podjęty przez Ewę Katarzynę Czech i Martę Czech (Kilka uwag na temat możliwości traktowania krajobrazu jako dobra osobistego w kontekście prowadzenia działalności gospodarczej). Niewątpliwie „zeszpecenie krajobrazu może oddziaływać na stan psychiczny człowieka i może przy długotrwałym istnieniu tego źródła stresu wpływać na zdrowie psychiczne, a także fizyczne jednostek" (s. 251). Naruszenie krajobrazu poprzez prowadzenie działalności gospodarczej w sposób sprzeczny z prawem może zmuszać do przeniesienia miejsca swej aktywności życiowej. Temat poruszony przez autorki jest więc nad wyraz istotny, szczególnie wobec szczupłości orzecznictwa. Mankamentem stylistycznym w tym rozdziale jest - w moim odczuciu - odpersonalizowanie cytowanych autorów przez co, na przykład, tytułowanie jednej z cytowanych autorem „,innym przedstawicielem prawa" daje sztuczny zabiegi językowy. Biorąc pod uwagę, że autorki przywoływały literaturę i orzecznictwo sprzed 1989 r. nie dostrzegłem w bibliografii pozycji Wojciecha Radeckiego z 1986 roku o ochronie dóbr osobistych ${ }^{1}$.

Adam Habuda (Prawne instrumenty reglamentacji działalności gospodarczej na obszarach chronionych) zebrał z pożytkiem dla czytelnika katalog zakazów prowadzenia działalności na obszarach chronionych. Zwrócił uwagę na różnice między obszarem Natura 2000 a innymi obszarami chronionymi. Omówił plan ochrony i ocenę habitatową. Reglamentacji nie upatrywałbym jednak $\mathrm{w}$ umocowanym prawnie ograniczeniu podejmowania i prowadzenia działalności gospodarczej (s. 34), ale na dopuszczaniu w określonym zakresie do korzystania z dobra, jakim jest przyroda.

Ogólny charakter posiada rozdział Joanny Kielin-Maziarz (Czy koncepcja zrównoważonego rozwoju ogranicza wolność działalności gospodarczej?), ale - moim zdaniem - autorka wadliwie go skonstruowała. Prowadziła w nim rozważania teoretyczne $\mathrm{w}$ nawiązaniu do prawa konstytucyjnego. Wiele

1 W. Radecki, Ochrona środowiska naturalnego a ochrona dóbr osobistych, [w:] J. Piątowski (red.), Dobra osobiste i ich ochrona w polskim prawie cywilnym. Zagadnienia wybrane, Wrocław 1986. 
miejsca poświęciła na definiowanie działalności gospodarczej, wolności działalności gospodarczej i jej ograniczeń, ważnego interesu publicznego oraz zrównoważonego rozwoju. Niecałe dwie strony tekstu (s. 81-83) przeznaczyła na konkretne omówienie obranego tematu. Na tytułowe pytanie odpowiedziała jednym zdaniem, owszem w nawiązaniu do zasady proporcjonalności. Jej rozdział pozostawia zatem widoczny niedosyt tym bardziej, że w mojej ocenie, zasada zrównoważonego rozwoju opacznie stosowana prowadzi często do przenoszenia inwestycji tam, gdzie środowisko naturalne chronione nie jest. Wywody zaś autorki - w mojej ocenie - rażą schematycznością.

Kinga Handzel-Urbańczyk (Problematyka swobody działalności gospodarczej w śweitle regulacji zwiazanych z europejska siecia Natura 2000) celnie wskazała, iż ustawodawstwo krajowe może być bardziej rygorystyczne od prawa unijnego, a istotną rolę $\mathrm{w}$ postępowaniach administracyjnych odgrywa swobodne uznanie. W interesujący sposób skomentowała orzecznictwo, podnosząc wątek obowiązku zebrania przez organ administracji publicznej dokumentacji dotyczącej innych wariantów inwestycji (s. 65). Rozważania autorki skłaniają do namysłu, czy formalistyczne podejście sądów w pewnych przypadkach może mijać się z realiami funkcjonowania administracji publicznej, nakładając na instytucje publiczne obowiązki trudne w praktyce do osiągnięcia. Ujmując krótko, tekst autorki jest - zdaniem niżej podpisanego - jednym $\mathrm{z}$ najbardziej wartościowych $\mathrm{w}$ recenzowanej monografii.

Kontynuacją rozdziału K. Handzel-Urbańczyk jest tekst Magdaleny Michalak (Odstepstwa od zakazu realizacji inwestycji mogacych znaczaco negatywnie oddziaływać na obszary Natura 2000 w orzecznictwie Europejskiego Trybunału Sprawiedliwości). Autorka, analizując wyroki, akcentowała konieczność oceny interesu publicznego i rozwiązań alternatywnych dla inwestycji, mogących negatywnie oddziaływać na tereny Natura 2000.

Wątek analizy orzecznictwa podjęli również Ryszard Mikosz i Grzegorz Dobrowolski (Zasada zrównoważonego rozwoju w orzecznictwie sąów administracyjnych). Przy tego typu tekstach brakuje jednak pogłębionego spojrzenia na orzecznictwo sądów polskich w sprawach karnych z zakresu ochrony środowiska. W literaturze przedmiotu wyróżniają się na tym tle publikacje wydane $\mathrm{w}$ zbiorze: Prawnokarne i kryminologiczne aspekty ochrony środowiska ${ }^{2}$.

${ }^{2}$ M. Kotowska, M. Duda, Kłusownictwo na wodach śródlądowych na przykładzie spraw w Sadzie Rejonowym w Olsztynie oraz M. Werbel-Cieślak, Wybrane aspekty przestępstw i przestępczości przeciwko środowisku (w świetle danych statystycznych i badań aktowych, [w:] W. Pły- 
Kolejno omówię artykuły szczegółowe. Krzysztof Chochowski (Zasada zrównoważonego rozwoju w prawie ochrony środowiska) wbrew tytułowi skupił się na problematyce kary pieniężnej w prawie ochrony środowiska. Wykorzystał niewielką liczbę pozycji bibliograficznych. Zabrakło też bezpośredniego odwołania do źródła, jakim jest: Sylvicultura oeconomica, oder haußwirthliche Nachricht und Naturmäßige Anweisung zur wilden Baum-Zucht Hansa Carla von Carlowitza, a dzieło to jest przecież dostępne bezpłatnie w Internecie.

Energią odnawialną zainteresowała się Anna Fogel (Ograniczenie możliwości inwestowania a ochrona walorów krajobrazowych obszarów chronionych na przykładzie inwestycji w energię odnawialna). Podobnie jak we wspomnianym rozdziale autorstwa J. Kielin-Maziarz, tytułowemu problemowi poświęcono tylko dwie strony (s. 269-271), więc z mojego punktu widzenia ten rozdział jest zbyt zdawkowy.

O biogazowniach pisała Małgorzata Ganczar (Wpis do rejestru działalności regulowanej na przykładzie biogazowi jako forma reglamentacji działalności gospodarczej), falsyfikując na tym przykładzie tezę o liberalizacji działalności gospodarczej w Polsce. Rzeczowe uwagi do przyjętych rozwiązań ekologicznych we Wspólnej Polityce Rolnej zgłosili Beata Jeżyńska i Radosław Pastuszko (Ekologiczne aspekty Wspólnej Polityki Rolnej). Przydatny okazał się przeglądowy rozdział Bartosza Kusia o parku krajobrazowym (Działalność gospodarcza na obszarze parku krajobrazowego).

Problematykę robót geologicznych i wydobycia kopalin na obszarach chronionych omówił Aleksander Lipiński (Roboty geologiczne i wydobywanie kopalin na obszarach chronionych. Niektóre uwarunkowania prawne). Położył m.in. nacisk na rozproszenie regulacji prawnych $\mathrm{w}$ tej mierze, co może być uciążliwe dla obywateli, ale stanowi też wyzwanie dla przedstawicieli nauki prawa. Minusem tekstu są najbardziej niestaranne przypisy ze wszystkich rozdziałów recenzowanej książki i przewaga autocytowań. Przywołana przez autora literatura nie znalazła się w bibliografii, a w dodatku książka Grzegorza Dobrowolskiego została błędnie zacytowana ${ }^{3}$.

Tomasz Sienkiewicz (Układ urbanistyczny wpisany do rejestru zabytków jako nienazwana forma ochrony przyrody) postawił pytanie: „czy formy zaprojektowanej zieleni mogą podlegać ochronie na podstawie ustawy o ochronie zabytków i opiece nad zabytkami?" (s. 289). Odpowiedział na nie twierdząco, wskazując na pozycję administracji ochrony zabytków,

waczewski (red.), Prawnokarne i kryminologiczne aspekty ochrony środowiska, Olsztyn 2012, s. 265 i 297.

3 Powinno być: G. Dobrowolski, Decyzja o środowiskowych uwarunkowaniach, Toruń 2011. 
opisując pojęcie układu urbanistycznego i dotykając wątku reklam wielkogabarytowych. Powstał tym sposobem interesujący artykuł ubogacający recenzowaną książkę.

Trudnym zagadnieniem współuczestnictwa jednolitego zajęła się Agnieszka Skóra w rozdziale: Konstrukcja wspótuczestnictwa w sprawie pozwolenia na budowe w postępowaniu wymagajacym udziału społeczeństwa (uwagi na marginesie ustawy z dnia 3 października 2008 r. o udostępnianiu informacji o środowisku i jego ochronie, udziale społeczeństwa w ochronie środowiska oraz o ocenach oddziaływania na środowisko). Autorka spojrzała na przepisy z zakresu ochrony środowiska przez pryzmat procedury administracyjnej. Jej wywody są jasne, dzięki czemu czytelnik dowie się na przykład: o relacjach łączących poszczególne strony postępowania, źródłach interesów prawnych osób innych niż inwestor.

Małgorzata Szalewska (Ochrona obszarowa przed hałasem) scharakteryzowała prawne formy ochrony przed hałasem, $w$ tym obszar cichy w aglomeracji. W przystępny sposób połączyła wątki teoretyczne ze szczegółowymi. Nasuwa mi się jedna drobna uwaga, gdyż zabrakło w tekście przypisu do przytoczonej definicji hałasu.

Pokrewnym w stosunku do rozdziału A. Fogel jest artykuł Karoliny Szumy (Ograniczenie wolności działalności gospodarczej prowadzonej z wykorzystaniem odnawialnych źródet energii ze względu na prawna ochronę krajobrazu). Tytuł wprowadza czytelnika w błąd, gdyż autorka omówiła temat budowy farm wiatrowych na obszarach Natura 2000 na przykładzie włoskiego regionu Apulia. Tezy autorki budzą uwagę, przede wszystkim odnośnie zakazów inwestowania, ale czytelnik zainteresowany włoskim prawem do rzeczonego tekstu nie dotrze, gdyż nawet słowa kluczowe nie są dopasowane do treści. Części ze wskazanej literatury nie ma zresztą w bibliografii.

Jacek Trzewik (Park kulturowy jako forma ograniczenia działalności gospodarczej) zaprezentował pożyteczny katalog ograniczeń prowadzenia działalności gospodarczej w parkach kulturowych. Jego tekst, o zbiorczym charakterze, obok rozdziałów B. Kusia i T. Sienkiewicza, niewątpliwie przyczyni się do popularyzacji wiedzy na temat prawnych uregulowań ochrony środowiska naturalnego.

Wśród artykułów tej części wyróżnia się tekst Agnieszki Żywickiej o obrocie środkami roślin i ich konfekcjonowaniu (Zasada zrównoważonego rozwoju a prowadzenie działalności gospodarczej na przykładzie działalności $w$ zakresie obrotu środkami ochrony roślin lub ich konfekcjonowania). Wywody autorki są konkretne, a lista uprawnień inspekcji ochrony środowiska pomocna. Ujęcie norm prawnych z punktu widzenia teorii konfliktu ze 
wskazaniem na możliwości jego przezwyciężenia dzięki inicjatywom organów administracji publicznej, to istotny wkład w treść książki.

Studia przypadków reprezentowane zostały w monografii przez dwa teksty. Małgorzata Gałczyńska i Anna Haładyj zajęły się „Partnerstwem Naturowym" (Koncepcja wspótpracy międzysektorowej w ochronie środowiska na przykładzie Lubelskiego Partnerstwa Naturowego). Postawiły trafną tezę, iż na obszarach Natura 2000 prowadzenie działalności gospodarczej, w tym rolniczej, rybackiej i leśnej jest nie tylko dopuszczalne, ale czasem wręcz pożądane (s. 87). Zebrały też przydatne dane o obszarach naturowych. Rozumiem zaangażowanie autorek, ale odniosłem wrażenie o niewspółmierności założeń Lubelskiego Partnerstwa Naturowego („dążenie do samowystarczalności energetycznej gmin województwa lubelskiego" s. 97) z działaniami projektu i kosztami akcji promocyjnej. Nie wiem, czy projekt ten przyczyni się do realizacji tak ambitnego zadania.

Piotr Zacharczuk, w rozdziale zamykającym książkę, zainteresował się Południowomałopolskim Obszarem Chronionego Krajobrazu (Dziatalność gospodarcza na obszarze chronionego krajobrazu na przykładzie Południowomałopolskiego Obszaru Chronionego Krajobrazu). Autor zwrócił uwage czytelnika na nieracjonalną rozbieżność w podejściu władz samorządowych do obszarów chronionego krajobrazu. Jest ono diametralnie różne od nastawienia wobec parków narodowych. Dzieje się tak mimo związanych z obszarami chronionymi ograniczeń w podejmowaniu działalności gospodarczej. Może się na przykład okazać, że część obostrzeń pozostaje „na papierze”, a niektóre nie są do końca przemyślane. Przykładem, podanym przez P. Zacharczuka, jest budowa małych elektrowni wodnych pożądanych na terenach górzystych (s. 356).

Jeśli chodzi o stronę redakcyjną to częstym błędem Wydawnictwa KUL, który został powielony i wypadku tej pozycji, jest brak wskazanego stanu prawnego. Między treści książki wkradły się drobne błędy drukarskie, ale bardziej brakuje jednolitej maniery redakcyjnej poszczególnych rozdziałów, które po prostu nie zostały ujednolicone. W książce, dla przykładu, raz pojawia się skrót „s." na oznaczenie strony, a innym razem „str.", przy czym optować by należało za pierwszym rozwiązaniem. Różna jest pisownia nazwisk złożonych, gdyż w tekstach mylono dywiz z półpauzą. W przypisach autorzy albo powinni podawać pełne dane wydawnictw, albo tego zaniechać, a różnice spotkać można nawet w obrębie jednego rozdziału. Dowolnie zapisywano nazwę wydawnictwa „Wolters Kluwer". Tytułów czasopism nie ujmowano w cudzysłów i nazbyt swobodnie posługiwano się kursywą. Skróty publikatorów urzędowych podano niespójnie, tak samo skrót od słowa "tom”. Niejednakowo notowane 
są dane bibliograficzne prac wydanych pod redakcją. Niektórzy autorzy mnożyli omyłki w jednym przypisie zapisując numer danego czasopisma wielką literą i przestawiając dane redaktora (przypis nr 3, s. 113). Jeden z autorów zastosował nie tylko własny - obfitujący w błędy - zapis bibliograficzny, ale nawet system skrótów, nieprzystający do przyjętego przez redaktorów (s. 199-217). W tym wypadku autor z nonszalancją podszedł nie tylko do aparatu naukowego, ale i stylu, gdyż nagminnie powtarzał frazę: „Brak miejsca nie pozwala na rozwinięcie...”. Jest to o tyle frapujące, że niedomagania znalazły się zwłaszcza $\mathrm{w}$ artykułach przygotowanych w ramach projektów finansowanych ze środków Narodowego Centrum Nauki. Wykaz skrótów i bibliografia nie zawierają wszystkich pozycji i skrótów przywołanych przez autorów. Bibliografii nie rozdzielono na źródła, literaturę i strony internetowe przez co znalazły się w niej materiały Generalnej Dyrekcji Ochrony Środowiska (s. 364) i pismo Generalnego Dyrektora Ochrony Środowiska (s. 370). Strony internetowe cytowano bez spójnej reguły. Innymi słowy, redaktorzy powinni wkładać większy wysiłek w przygotowanie technicznej strony przesyłanych im tekstów.

Zastosowali za to bardzo dobre rozwiązania, ułatwiające upowszechnianie dorobku przez autorów samodzielnie zamieszczających noty bibliograficzne w bazach danych. Każdy rozdział posiada tytuł, abstrakt oraz słowa kluczowe $\mathrm{w}$ językach polskim i angielskim, a dodatkowo notę autorską wraz z afiliacją i adresem e-mail. Kończąc nie zaszkodzi skierować słów pochwały pod adresem projektantki finezyjnej okładki.

rec. Karol Dąbrowski

* Dr, Uniwersytet Marii Curie-Skłodowskiej w Lublinie; karol.dabrowski@poczta. umcs.lublin.pl. 